\title{
OSMIČKOVÉ VÝROČIA V PEDAGOGICKOM KONTEXTE
}

\author{
EVA VITÉZOVÁ
}

VITÉZOVÁ, Eva: Years of "Eights" in Pedagogical Context, 2019, Vol. 1, Issue 1, pp. 103 - 110. DOI: 10.17846/CEV.2019.01.1.103-110.

\begin{abstract}
In terms of significant historical anniversaries, the year 2018 is exceptional and extraordinary for Slovakia. During the year, we commemorate many anniversaries with both positive and negative connotation. Today's teachers have to deal with a challenge of transformation of these anniversaries into the pedagogical process. We will pay attention to this issue in our contribution.
\end{abstract}

KEYWORDS: Pedagogical Process. Anniversaries. Lesson. Literature. Theatre.

Rok 2018 bol pre Slovensko z hladiska významných dejinných výročí výnimočný a mimoriadny. V priebehu roka 2018 sme si pripomenuli 25. výročie vzniku Slovenska ako suverénneho štátu, 100. výročie založenia prvej ČSR a konca prvej svetovej vojny, 50. výročie Pražskej jari či 30. výročie sviečkovej manifestácie za náboženskú slobodu a demokraciu. Okrúhle jubileá narodenia mali viaceré osobnosti: osvietenský vedec, ktorý ovplyvnil školskú reformu Márie Terézie - Adam František Kollár; politik a štátnik Milan Hodža; architekt Dušan Jurkovič; maliar Martin Benka; herec, režisér, scénický výtvarník a pedagóg Karol L. Zachar; hudobní skladatelia Jan Nepomuk Hummel a Eugen Suchoň; rozprávkar Pavol Dobšinský, filmový režisér a scenárista, spoluautor oscarového filmu Obchod na korze Ján Kadár; spisovatelia a básnici Ján Smrek, Martin Rázus, Maša Halamová, Milan Rúfus, Štefan Žáry, Rudolf Sloboda a iní. A sú tu aj výročia skôr smutné, ktoré vyplynuli z dátumov mníchovskej zrady (1938) alebo „Vítazného februára“ (1948). Do tejto kategórie patrí napríklad 50. výročie vpádu vojsk Varšavskej zmluvy na naše územie. Nemožno zabúdat ani na rok 1848 a s ním súvisiace udalosti, napr. reč Ludovíta Štúra na Uhorskom sneme o jazykových právach Slovákov, prijatie Žiadostí slovenského národa v Liptovskom Mikuláši, prvé zasadnutie I. Slovenskej národnej rady a pod.

Súčasní pedagógovia na všetkých typoch škôl stoja pred výzvou, ako (nielen) tieto výročia primerane pretransformovat' do pedagogického procesu. Vo svojom príspevku budeme venovat' pozornost' práve tejto problematike. Pripravili sme metodický materiál, ktorý môže byt' námetom na prepájanie jednotlivých predmetov, kompetencií i kontextov. Materiál sa týka stredoškolského prostredia a pôjde o tému Slovenský romantizmus (s dôrazom na štandardizované diela v kontexte rokov 1848/1849). Základným medzipredmetovým prepojením bude spojenie slovenského jazyka a literatúry s dejepisom, ale dôraz bude i na informatickej výchove (kritická práca s informáciami $\mathrm{v}$ internetovom priestore), ako i nadväzovanie na vedomosti, ktoré žiaci získali v predchádzajúcej školskej dochádzke a v priebehu svojho života. Všetky materiály boli reálne odprezentované vo vyučovacom procese. Na niektorých miestach v texte štúdie uvádzame i odkazy na internetové stránky - je tomu tak v tých prípadoch, ked’ boli stránky využité priamo vo vyučovaní a práca $\mathrm{s}$ nimi bola relevantná pre skupinovú či individuálnu činnost’ v rámci vyučovania. 


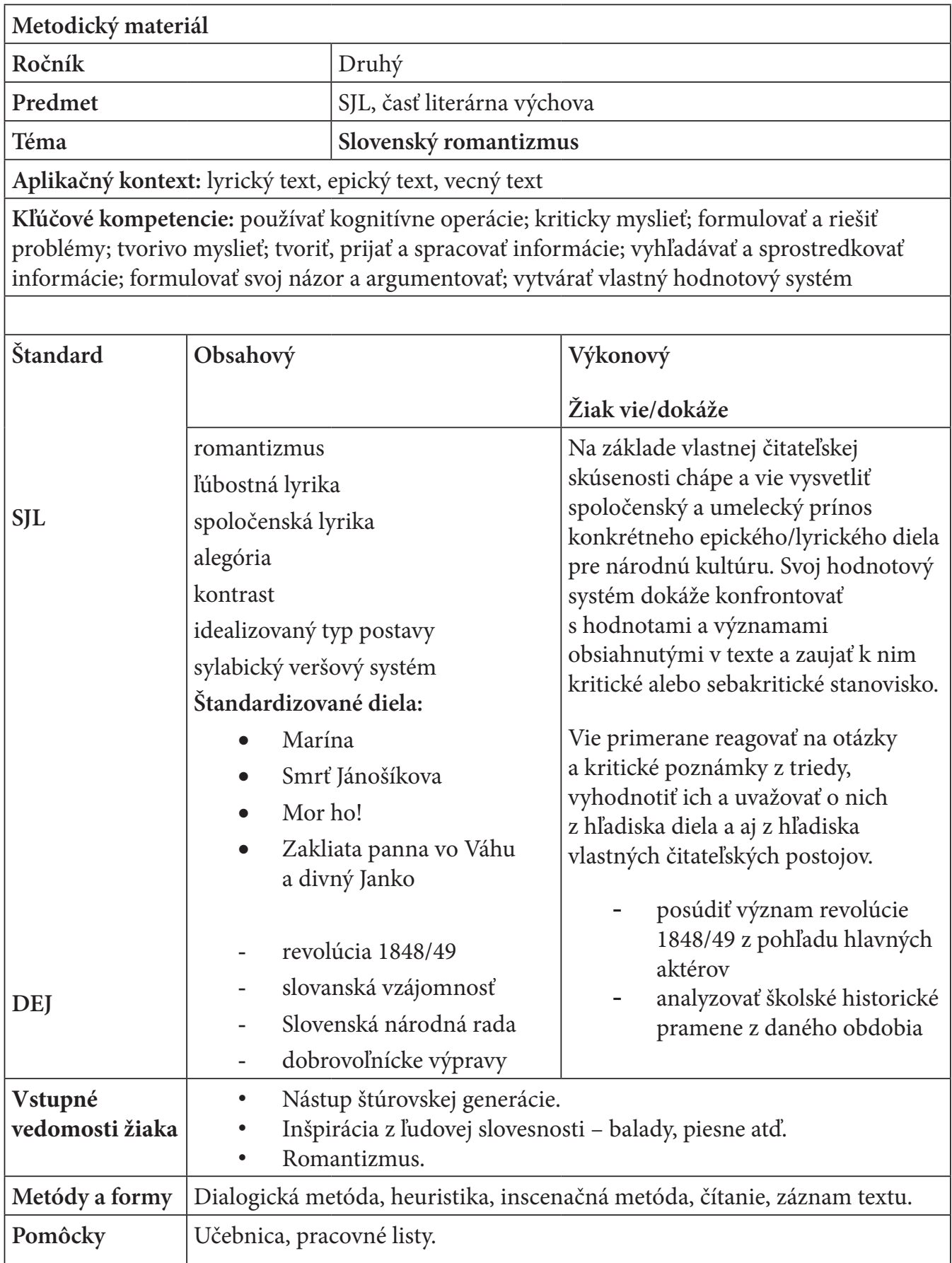


ROMANTIZMUS - PRACOVNÝ LIST

Spoločenský a historický kontext

\section{Ukážka 1}

Gróf Zay, generálny inšpektor evanjelikov (augsburského vyznania), vo svojej nástupnej reči, ktorá vyšla a bola rozšírená až v troch jazykoch, vyslovil sa o pomad’arčovaní takto: „Pomadarčovanie krajiny a jeho účinné napomáhanie je najsvätejšou povinnostou každého opravdivého vlastenca Uhorska, každého zástancu slobody a inteligencie, každého verného poddaného rakúskeho domu, ak nechce byt'zaslepencom a snaží sa vyhnút podozreniu z potutelných úmyslov. "1

1. Konfrontujte ukážku s informáciami na stránke: http://www.stur.sk/osoby/zay.htm.

Diskutujte. O čo sa snažili predstavitelia formujúceho sa mad’arského národa? Čo bolo príčinou sporu grófa Zaya a Ludovíta Štúra?

2. Zopakujte si vedomosti zo ZŠ:

Ako slovenskí národovci reagovali na súdobé národné a sociálne požiadavky európskych národov?

Objasnite pojem „meruôsmy rok“. Argumentujte. Vyhladajte slovo meruôsmy v elektronickom slovníku http://slovniky.juls.savba.sk/.

3. Čo viete o prvom politickom programe Slovákov?

http://www.mjk.sk/sk/pamatnik-ziadosti-slovenskeho-naroda

Zhromaždenie formulovalo Žiadosti slovenského národa v štrnástich bodoch.

Hranie roly. Predneste požiadavky v prvej osobe plurálu s využitím prvkov neverbálnej komunikácie.

1. Slovenský národ sa dovoláva rovnosti, slobody, bratstva pre všetky národy Uhorska.

2. Požaduje celouhorský snem, s právom pre zástupcu každého národa hovorit’ národnou rečou.

3. Žiada osobitné národné snemy pre jednotlivé národy žijúce v Uhorsku a ohraničené podla národných hraníc.

4. Zástupcovia jednotlivých národov na celouhorskom sneme mali sa spravovat podla úprav, ktoré dostali od tých, čo ich na snem vyslali. V opačnom prípade mal ich stíhat trest.

5. Pri rokovaniach o verejných veciach sa mala používat materinská reč.

6. Zriadenie národných škôl, od základných, meštianskych, reálnych, dievčenských ústavov až po učitel'ské semináre, vyššie literárne kňazské ústavy, gymnáziá, lýceá, akadémie, polytechnický ústav a jednej univerzity.

7. Slovenčina sa mala zaviest’ do všetkých škôl, počnúc l’udovými a končiac univerzitou. Mad’arské stolice mali zakladat' vo svojich školách katedry slovenskej reči pre Madarov a slovenské stolice zasa katedry mad’arskej reči pre Slovákov, aby sa oba národy vzájomne zblízili.

\footnotetext{
Dostupné na internete: https://zlatyfond.sme.sk/dielo/1278/Stur_Obranne-boje/3\#ixzz5Rp8UX318
} [15. 1.2019]. 
8. Žiadosti žiadali odstránit v Uhorsku panovanie jedných národov nad druhými národnostami. Žiadosti spomínajú aj slobodné používanie národných farieb. Velitelmi národných gárd na Slovensku mali byt Slováci a veliacou rečou mala byt slovenčina.

9. Slováci žiadali všeobecné volebné právo. Úradníkmi mali byt̉ len verní synovia národa a odrodilstvo sa malo trestat ako zrada na národe a vlasti.

10. Požadovala sa i sloboda tlače, zhromaždovacie a spolčovacie právo, ako i zabezpečenie osobnej slobody pri cestách po krajine.

11. Usporiadanie agrárnych pomerov: lesy, kopanice, lúky a pastviny, ktorých sa lud zmocnil v prvých dňoch slobody, a ktoré im páni znovu odobrali, mali sa ludu vrátit.

12. Prepustenie slovenských národovcov Janka Krála a Jána Rotaridesa, väznených preto, že v Príbelciach verejne poučovali slovenský lud o nových zákonoch.

13. Uvolnenie polského národa $\mathrm{v}$ Haliči, aby sa mu konečne dostalo milosti a spravodlivosti.

14. Mikulášske Žiadosti slovenského národa pokladali splnenie týchto spravodlivých žiadostí za podmienku štastia slovenského národa a zabezpečenia jeho národnosti. ${ }^{2}$

Metodický materiál č. 2 - Romantizmus

\begin{tabular}{|c|c|}
\hline Téma & Ročník \\
\hline Romantizmus & 2. ročník SŠ \\
\hline Spoločenský a historický kontext & (2 vyučovacie hodiny) \\
\hline Žiak sa naučí & Vstup \\
\hline $\begin{array}{l}\text { Spôsobilost’ tvorivo mysliet’ a uplatnit’ výsledky } \\
\text { tvorivého myslenia }\end{array}$ & Vedomosti o romantizme $\mathrm{z}$ nižších ročníkov \\
\hline Čo si žiak osvojí & Didaktický problém \\
\hline $\begin{array}{l}\text { Využíva spôsoby a mechanizmy vyhladávania } \\
\text { informácií. } \\
\text { Komunikuje prostredníctvom IKT. } \\
\text { Realizuje čiastkové úlohy a výstupy } \\
\text { z vyučovania. } \\
\text { Používa kognitívne operácie. } \\
\text { Formuluje a rieši problémy. }\end{array}$ & $\begin{array}{l}\text { Dávame žiakovi priestor na sebavyjadrenie. } \\
\text { Pomáhame žiakovi verbalizovat čitatel'ský } \\
\text { zážitok, vytvárat' vlastný hodnotový systém. }\end{array}$ \\
\hline Prostriedky & Metódy a formy \\
\hline $\begin{array}{l}\text { Interaktívna tabula } \\
\text { Učebnica } \\
\text { Pracovný list }\end{array}$ & $\begin{array}{l}\text { Hladanie a spracovanie informácií } \\
\text { Diskusia } \\
\text { Kooperácia }\end{array}$ \\
\hline
\end{tabular}

2 http://www.oskole.sk/?id_cat=56\&clanok=22955 [15. 1. 2019]. 


\section{Štruktúra modulu}

\section{1. hodina}

Práca s informáciami, diskusia, práca s textom.

Domáca úloha na prezentácii bude zverejnená na webe.

2. hodina - prezentácie domácich úloh na interaktívnej tabuli, analýza práce, vpisovanie do prezentácie a pod.

Epickú i lyrickú poéziu je vhodné podávat žiakom zážitkovou formou. Žiaci sa takto na vlastnej koži presvedčia, že písanie veršov nie je iba zaznamenávanie iracionálnych pocitov, ale riadi sa určitými pravidlami.

Korene našej štátnosti - učivo z dejepisu možno preberat’ v rodnom dome L. Štúra v Uhrovci. Študenti sa môžu zhostit úlohy sprievodcov.

Prvý politický program Slovákov môže byt aj námetom exkurzie v Liptovskom Mikuláši (Múzeum Janka Krála, Demänovská jaskyňa slobody, kde sa na jaskynnej stene zachovali podpisy štúrovcov). Žiaci zbierajú a triedia informácie, referujú pred spolužiakmi.

Epická poézia - Janko Král: Zakliata panna vo Váhu a divný Janko - žiaci si pripravujú materiál stiahnutý z internetových stránok a konfrontujú s primárnym zdrojom, knihou. Objavujú chyby, ktoré sú prítomné v referátoch na internete.

Krátka epická próza. Vyučovanie v knižnici - integrácia jazykovej, literárnej a slohovej zložky s dejepisom. Slovenský jazyk a literatúra - Kukučín, Tajovský. Dejepis - Slováci v Rakúsko-Uhorsku.

Žiaci pracujú v skupinách v oddelení beletrie a odbornej literatúry. Každá skupina dostane úlohy, ktoré zahŕňajú učivo o poviedkovej tvorbe Tajovského, Kukučína a o spoločenských podmienkach v období nástupu literárneho realizmu.

V štvorhodinovom bloku skupiny zbierajú a spracúvajú informácie, čítajú poviedky, robia si poznámky. Výstupom budú prezentácie s dĺžkou prípravy jeden týždeň. Po týždni vystúpia vedúci skupín s prezentáciami aj v paralelnej triede.

\section{Námet na exkurziu: Zbojníckym chodníckom}

Organizačná forma: exkurzia spojená s vyučovaním v prírode

Téma:

Vonkajšia kompozícia: nadpis, strofa, verš - spev

Významová interpretácia - Ján Botto: Smrt’ Jánošíkova

Metódy: informačno-receptívna, reproduktívna, heuristika.

Motivácia - Po predchádzajúcich skúsenostiach s odovzdávaním výstupov z vyučovacích aktivít v niektorých triedach sme sa rozhodli, že urobíme niečo, čo pritiahne pozornoste žiakov a prinúti ich zamysliet sa nad tým, prečo si vybrali štúdium na strednej škole a aké povinnosti ich čakajú, aby štúdium aj úspešne absolvovali.

\section{Plánovanie}

Podnietili sme diskusiu žiakov tak, aby mali možnost' vyjadrit’ svoj vlastný názor, mohli prejavit’ vlastnú iniciatívu pri realizácii projektového vyučovania. Upozornili sme na skutočnost', že samotná exkurzia bez ich aktívnej pracovnej účasti nie je projektom, že musíme vyriešit problém nezvládnutého učiva tak, aby si osvojili náležité vedomosti a zručnosti. Spoločne sme sa dohodli na pláne a výslednom produkte. 
Eva Vitézová

\section{Realizácia}

Všetkým žiakom bolo jasné, kto, čo a ako urobí. V tejto fáze žiaci pracovali so zdrojmi informácií, zbierali materiál, podielali sa na organizačnom zabezpečení exkurzie.

1. skupina - zmapovanie trasy náučného chodníka Dolné diery (sprievodcovia).

2. skupina - zabezpečenie a vytlačenie jedálneho lístka Jánošíkovej koliby z internetu a zoznamu účastníkov. Každý účastník si vyberie z ponuky a informáciu dopíše k svojmu menu. Telefonické kontaktovanie zamestnancov koliby a dohodnutie sa o obede.

3. skupina - elektronická objednávka autobusu, vyzbieranie peňazí na dopravu.

4. skupina - informácie o zaujímavostiach Terchovej.

5. skupina - v spolupráci s druhou skupinou - zoznam žiakov, poučenie o bezpečnosti, zabezpečenie igelitového vreca na odpad.

Všetky skupiny - text Smrti Jánošíkovej, rozdelenie do pracovných skupín, interpretácia jednotlivých spevov.

\section{Program:}

Vychádzka náučným chodníkom Jánošíkove diery. Cestou k začiatku turistickej trasy sme sa zastavili v Bielom Potoku a odovzdali sme zamestnancovi Jánošíkovej koliby zoznam účastníkov s objednávkou jedla a dohodli sme sa, že asi pol hodinu pred príchodom sa skontaktujeme telefonicky. Zamestnanci nám vyšli maximálne v ústrety, rezervovali nám poschodie reštaurácie, pripravili jedálne lístky - pomôcky na čítanie a pripravili nám chutný obed.

Dolné diery jednoduchá trasa od Hotela Diery asi 40 minút.

Cestou sme zbierali odpadky po neporiadnych turistoch, prekvapili sme v kolibe Podžiar, ked' sme upratali aj okolie koliby, odpadky sme niesli zo sebou až do Štefanovej, kde ich žiaci vyhodili do kontajnera na parkovisku.

Odpočinok v kolibe Podžiar - občerstvenie 30 minút.

Vychádzka do Štefanovej - 20 minút.

\section{Námet na exkurziu: Brezová pod Bradlom}

Mohyla Milana Rastislava Štefánika sa nachádza na vrchu Bradlo (Košariská, tam je aj múzeum venované Štefánikovi). V Brezovej je Pamätná izba Dušana Jurkoviča a impozantný evanjelický chrám spojený s Hurbanom. Na Myjave sú zaujímavé artefakty v Múzeu Slovenských národných rád. Exkurziou náročnou na čas, ale bohatou na zážitky, je exkurzia v Hlbokom, na faru i do pamätnej izby.

\section{ZÁVER}

Osmičkové historické udalosti si treba určite pripomínat’ - i (a najmä) v školskom kontexte. Aká je ich výpovedná hodnota v našej dobe? Čo treba pripomínat mladej generácii? Mladým ludom treba osvetlit', že nič netrvá večne. Vel'ké a mocné impériá, ktoré pretrvali stáročia, môžu padnút. Takisto dôležitou skúsenostou je fakt, že ustupovanie zlu nevedie k jeho zastaveniu a že diktatúra sa k moci môže dostat' i naoko demokratickou cestou. Vytvorit štát je len začiatok, treba sa naučit si vládnut' - a taktiež skúsenost', že akokolvek neohrozene a neochvejne moc pôsobí, môže padnút'. V súčasnej škole je vhodné (ba až nevyhnuté) prepájat školské vyučovanie s praxou, vyučovanie o literatúre a dejinách prepájat zakladat na čítaní „živej literatúry“, históriu, literatúru, kultúru sprostredkúvat prostredníctvom zážitku. Preto na záver našej štúdie vymenujeme aspoň niekolko literárnych diel a divadelných predstavení, ktoré možno zužitkovat pri „osmičkovom“ roku. Ide napríklad o tieto tituly: Jozef Banáš: Zastavte Dubčeka! (2009), Jozef Banáš: Prebijem sa! Štefánik 
(2018), Milan Kšiňan: Milan Rastislav Štefánik (2012), Mariana Čengel Solčanská: Generál M. R. Štefánik (2018). Divadelné predstavenia Radošinského naivného divadla: Malý velký muž (autor hry a textov piesní: Stanislav Štepka, muzikálový príbeh zo života M. R. Štefánika, premiéra 2. 6. 2018), Generál (autor hry Stanislav Štepka, premiéra 5. a 6. 4. 2004), Divadlo Andreja Bagara v Nitre: Štefánik - Slnko v zatmení (premiéra 24. 6. 2017).

\section{SUMMARY}

In terms of significant historical anniversaries, the year 2018 is exceptional and extraordinary for Slovakia. We commemorate the 25th anniversary of the Establishment of the Slovak Republic as a sovereign state, the 100th anniversary of the Establishment of the First Czechoslovak Republic, the 50th anniversary of the Prague Spring and the 30th anniversary of the Candle Manifestation for religious freedom and democracy. The year 2018 is also connected with the birth anniversaries of several personalities: politician and statesman Milan Hodža, architect Dušan Jurkovič, painter Martin Benka, fairy tale writer Pavol Dobšinský, writers and poets Ján Smrek, Martin Rázus, Milan Rúfus and others. There are also sad anniversaries that are connected with the Munich Betrayal or with the „Victorious February“. Today's teachers need to deal with a challenge of transformation of these anniversaries into the pedagogical process. We paid attention to this transformation of concrete events and anniversaries into pedagogical process in our contribution. We offered two lessons that are appropriate for upper secondary education. These lessons penetrate the sphere of literature, language teaching, history, as well as other teaching subjects related to this topic.

\section{LITERATÚRA}

Banáš, Jozef, 2009. Zastavte Dubčeka! Bratislava: Ikar.

Banáš, Jozef, 2018. Prebijem sa! Štefánik. Bratislava: Ikar.

Čengel Solčanská, Mariana, 2018. Generál M. R. Štefánik. Bratislava: Ikar.

Dvořák, Karel, 2012. Čítanka pre 2. ročník gymnázií a stredných odborných škôl. Harmanec: VKÚ. Gregorová, Ivana - Lapitka, Marián, 2012. Literatúra pre 2. ročník gymnázií a stredných odborných škôl. Bratislava: Slovenské pedagogické nakladatel'stvo - Mladé letá.

Krasnovský, Branislav - Ulrichová, Barbara - Bednárová, Marcela, 2011. Dejepis pre 8. ročník základnej školy a 3. ročník gymnázia s osemročným štúdiom. Martin: Matica slovenská.

Kšiňan, Milan, 2012. Milan Rastislav Štefánik. Brno: Computer Press.

Polakovičová, Alena, 2017. CD Čítame ušami 2 - zvukové nahrávky k Literatúre 2. Bratislava: Orbis Pictus Istropolitana.

Polakovičová, Alena - Caltíková, Milada - Štarková, L’ubica - Mezeiová, Adelaida, 2011. Literatúra II. pre stredné školy. Bratislava: Orbis Pictus Istropolitana.

Polakovičová, Alena, 2011. Zbierka textov a úloh z literatúry 2. Bratislava: Orbis Pictus Istropolitana. Slovníky. http://slovniky.juls.savba.sk/.

Stručné životopisy osobností spätých so životom a tvorbou Ludovíta Štúra. http://www.stur.sk/ osoby/zay.htm.

Štúr, Ludovít. 2010. Obranné boje. https://zlatyfond.sme.sk/dielo/1278/Stur_Obranne-boje/ 3\#ixzz5Rp8UX318.

Žiadosti slovenského národa. http://www.oskole.sk/?id_cat=56\&clanok=22955.

Múzeum Janka Krála, Pamätník Žiadostí slovenského národa. http://www.mjk.sk/sk/pamatnikziadosti-slovenskeho-naroda. 
Eva Vitézová

KONTAKT

prof. PaedDr. Eva Vitézová, PhD.

Katedra slovenského jazyka a literatúry

Pedagogická fakulta TU v Trnave

P. O. Box 9

91843 Trnava

Slovenská republika

eva.vitezova@truni.sk 